\title{
The Nature and Accumulation of Organizational Competences/Capabilities
}

\author{
Benjamin Coriat \\ Professor of Economics - Université Paris \\ Giovanni Dosi \\ Director, D octorate in Economics, Sant'Anna School of Advanced Studies, Pisa, Itália
}

\begin{abstract}
This paper addresses the nature of corporate organizations, their "competences" and "capabilities" and their learning patterns. The analysis is undertaken at different levels of observations- ranging from firm-level studies of thepatterns of technological and organizational change all the way to broad cross-national comparisons.'

The analysis of the nature of corporate organizations, their "competences" (or "capabilities"), their learning patternsand their embeddednessinto broader national and sectoral institutions is possibly one of the most activeareas of microeconomic research with important ramifications into multiple domains of investigation including the relationships between technological and organizational innovation, the vertical and horizontal boundaries of thefirm and the role of institutions. Indeed, it is our general conjecture that the nature of business organization, their competences/capabilities and their strategic orientation - embedded as they arein specific national institutions- arecrucial not only for theperformance of individual firms but also for the competitiveness and growth of wholenations and regions.
\end{abstract}

KEYwo RDS $\mid$ O rganizational Learning; Technological C apabilities; Competences; Learning Patterns; Problem-Solving.

Jel-Codes $\mid 012,030$

\footnotetext{
1 This paper builds upon the first part of the Final Report of the Dynacom Project, supported by the European Union and upon the introduction to Dosi, Nelson and Winter (2000). A complementary article, building on the same roots has been published in the Revista Brasileira de Inovação, Volume 1, Número 1, Janeiro/Junho de 2002. ISSN 1677-2504.
} 
RESUMO

Este artigo remete-se à natureza das organizações corporativas, suas "competências" e "capacitações" e seus padrões de aprendizado. A análise é realizada em diferentes níveis de observação - que vão dosestudosno nível das firmas, sobre seus padrões de mudança tecnológica eorganizacional, atéamplas comparações entrenações.

A análise da natureza dasorganizações corporativas, suas "competências" (ou "capacitações"), seus padrões deaprendizado e seu enraizamento em quadros institucionais nacionai se setoriaisé, possivelmente, uma das áreas da pesquisa microeconômica mais atuais, com importantes ramificações em múltiplos domínios da investigação, incluindo as relações entre inovação tecnológica eorganizacional, asfronteiras verticaise horizontais dafirma eo papel das instituições. D efato, énossa proposição geral quea natureza das empresas, suas competências/capacitaçõese sua orientação estratégica - enraizadas como estão em instituições nacionais específicas - são cruciais não somente para o desempenho das firmas individuais mas também para a competitividadee crescimento dasnaçõese regiões.

Palavras-Chave | Aprendizado O rganizacional; CapacitaçõesTecnológicas; Competências, Padrões deA prendizado; Solução deProblemas

Códigosjel $\mid 012,030$

\section{Introduction}

It isfamiliar enough that business firms and other organizations "know how to do things" - things like building automobiles or computers, or flying usfrom one continent to another. On second thought, what does this mean? Is there not a sense in which only a human mind can possess knowledge? If so, can this proposition somehow be squared with theidea that organizationsknow how to do things? And if organizational knowledge is a real phenomenon, what arethe principles that govern theway it is acquired, maintained, extended, and sometimes lost?

0 ur focus here is on the particular forms of organizational knowledge that account for theorganization's ability to perform and extend its characteristic "output" actions- particularly, thecreation of a tangible product or theprovision of a service, and the development of new products and services. The range of activities we have in mind is broad, embracing for example automobile manufacturing, brain surgery, identifying and developing new pharmaceuticals, 
putting on an effective art exhibition, and shipping a package across a continent. Pending a more thorough discussion of terminology, we identify the term "organization competences or capabilities" with the know-how that enables organizations to perform these sorts of activities.

In a first instance, let us just build on the idea that organizational knowledge is a fundamental link between some collective pool of knowledge/ skills/incentives opportunities, on the one hand, and the rates, directions and economic effectiven ess of this exploration/ development/ exploitation, on the other.

In turn, distinctive organizational competences/capabilities bear their importance insofar as they can be shown to persistently shape the destiny of individual firms - in terms of e.g. profitability, growth, probability of survival -, and, at least equally important, the patterns of change of broader aggregates such as particular sectors and whole countries. [For a more in-depth dimension of organizational microfoundations of competitiveness and growth, cf. among others, Coriat and D osi (1998a)].

These are thegeneral ideas that weshall explore in the following, starting with an in-depth inquiry into the nature and determinants of organizational competences/capabilities and exploring a few ramifications of such a perspective including the relationships between technological and organizational innovation, the vertical and horizontal boundaries of the firm, the links between firmspecific capabilities and industry-wide "technological regimes", and the role of country-specific institutions.

\section{Nature, dynamics and performance outcomes of firms competences/capabilities ${ }^{2}$}

\subsection{Organizational competences/capabilities}

To be capable of some thing is to have a generally reliable capacity to bring that thing about as a result of intended action. Capabilities fill the gap

\footnotetext{
2 Many more details of the interpretation which follows may be found in the Introduction to Dosi, Nelson and Winter (2000a); Marengo et al. (2000b); Dosi and Marengo (1999b); Coriat (2000a and 2000b) upon which this report is partly based. For critical essays of the literature cf. Weinstein and Azoulay (1999b) and Bezza (1999b).
} 
between intention and outcome, and they fill it in such a way that the outcome bears a definite resemblance to what was intended.

In the behaviour of organizations, however, the most relevant intentions are often remote from the particular action and outcome. They may lie deep in the background of the specific actions that occur, which often come about in a variety of ways not involving intentions - including habitual responses of human beings and the automatic, physically determined responses of machines. The local telephone company intended to provide phone service in the sensethat its executives, past and present, construed many of their own decisions in those terms - but the realization of a particular call is automatic. Its feasibility reflects an accumulation of equipment, individual skills, and organizational arrangements generated by a series of specific decisions that implemented and re-implemented the general intention to provide phone service - including a variety of arrangements that link the services of the provider of local service to other organizations in the global telecommunications system.

This example illustrates the typical situation: it is in the building of organizational capabilities that the role of intentionality is most reliably displayed; specific exercise may be intentional (as when an engineering firm build a factory or bridge to fulfil its contract to do so), but it may be also quite automatic (as in the phone-call example).

Although the phone call is a simple and familiar action from the caller's point of view, it ismadefeasible by the operation of an extraordinarily complex system. The system in turn is the product of a long and complex process of technological and organizational change, with associated investments in facilities and training - a process in which intentions to develop a (better) telephone system played a role that was important but intermittent and fragmented. The contemporary global telecommunications system was not produced through the execution of a coherent and comprehensive plan. In this case, and many others, the structure of capabilities at the highest level reflects the outcome of a self-organizing, bottom-up process rather than realization of any comprehensive intention.

The distinction we make here - between the capability itself and the numerous instances of its exercise- parallels similar distinctions expressed in 
varying terminology about a variety of contexts. In particular, it parallels the distinction at the individual level between a skill and the exercise of the skill. In organizations, there is a distinction between the execution of highfrequency, repetitive daily business by low-level employees and the decision of executives about the devel opment and deployment of capabilities (serving French fries vs. opening another hamburger stand). T here is a corresponding distinction at the individual level between the relatively tacit, subconscious, automatic, and highly-frequency character of exercise and the moreintentional, deliberate, and intermittent processes involved in skill development and deployment (learning to drive or choosing the destination vs. the exercise of skill in keeping the car on the road). The parallels extend to learning processes; different processes are involved in the sort of learning that improves exercise than in original development of skill and capabilities. This parallelism presents an opportunity to use the individual realm as a metaphor to explicate the organizational, and viceversa.

It has been said that the mark of high skill in an individual is theability to make some activity look easy when it is actually very difficult, and much the same point applies to organizational capabilities. The more polished the performance, the less attention is directed to the innumerable hazards of failure that have been overcome, and the more the performance itself takes on a taken-for-granted character.

Also, performances that are commonplace, in the sense of being reproduced at high frequency, come to seem less mysterious and easi er than accomplishments that occur only occasionally - al though it should beobvious on reflection that frequency per se is no indicator of ease or difficulty, once the threshold question of feasibility is settled. (For example the more organizations succeed in making customer encounters simpleand uneventful, the more the complex reality of capabilities tends to disappear behind the veil of familiarity).

\subsection{Some notes on terminology}

As al ready warned, we have kept so far a general equival ence between "competences" and "capabilities". 
Indeed both terms "capabilities" and "competences" float in theliterature like icebergs in a foggy Arctic sea, two icebergs among many not easily recognized as different from several icebergs nearby. $\mathrm{H}$ ence, it might be appropriate to survey these terminological flotilla and point out some distinctive feature of these diverse floating objects.

Following the discussion above, it should be clear that we think of "capability" as a fairly large-scale unit of analysis, one that has a recognizable purpose expressed in terms of the significant outcomes it issupposed to enable, and that issignificantly shaped by conscious decision both in its development and deployment. These features distinguish "capability" from "organizational routines" as that term is used in organization theory and evolutionary economics - subject to the qualification that some organizational routines might equally well be called capabilities. In general, however, the notion of a routine involves no commitment regarding size (large routines are typically structured sets of medium-sized ones, and so on). It involves no presumption regarding evident purpose: one of the interesting things about routines is indeed that they are often found in contexts where nobody can explain what they are for except in the vague terms of "the way things are done around here". And there is no presumption of deliberation or conscious choice; a flight crew probably does not choose its response to unexpected turbulence any more than a batter chooses to hit the dirt when the pitch appears to be coming towards his head.

On the other hand, the notion of a routine certainly does not exclude the possibility of conscious decisions about exercise. $\mathrm{H}$ ence, some routines may appropriately be called capabilities, if they satisfy the other criteria.

Capabilities involve organized activity and the exercise of capability is typically repetitious in substantial part. Routines are units or "chunks" of organized activity with a repetitive character. $\mathrm{H}$ ence, it is basically well said that "routines are the building blocks of capabilities" - although routines are not the only building blocks of capabilities. A marketing capability might require a customer database, for example, which is neither a routine itself nor does it resemblea routine in the way that the working of complex equipment sometimes does. The database is, instead, a contextual requisite of some of the organizational routines supporting the capability. 
Individual skills, in turn, areamong the building blocks of organizational routines. What we commonly think of as individual skills are quasi-modular components of routines; their namesare useful in expressing, for example, the idea that the roleplayed by one skilled machineoperator might well be played by another. But "knowing the job" involves knowing things that are relational - involving other participants- and organization-specific (N elson and W inter, 1982:100-3) That is why the skilled operator still needs to learn the job when joining an unfamiliar organization to operate a familiar machine - and why someone who is a perfectly adequate machine operator might nevertheless fail to learn the job. Some of the non-modular knowledge required is skill-like, regardless of what it is called - but these are skills that can be learned only through experiencein the specific organization.

In our view, clarity would be served by reserving the term "skills" to the individual level and "routines" to the organizational level. "Routines are the skills of an organization" is a metaphorical truth not a literal truth. ${ }^{3}$ In the existing literature, however, our proposed usage convention is violated in both directions. For example, Waterman et al. (1980) used "skills" for what wewould prefer to call routines or capabilities, whereas N el son and W inter (1982:100) slipped into using "routines" at theindividual level when they should have said "skills" or perhaps "constituent skills". Transgressions of thiskind will no doubt continue but, wehope, not by us.

Consistent with this proposal, a useful meaning for the "skills of the organization" would simply bethe collectivity of skills possessed by individuals in the organization, regardless of whether the skills are modular, organizationspecific, or not organization-related at all. Then it could be said that organizational routines have the major function of coordinating the skills of the organization, i.e. of turning that collectivity of skills to useful effect.

Turning to another area of the concept flotilla, we find a cluster centered on "competence".

Thenotion deservessomedetailed discussion also in that it appearsin the very title of this article - although in an expansiveinterpretation which makes it largely indistinguishable from the notion of "capability" discussed so far.

\footnotetext{
3 The statement is in Nelson and Winter (1982:124), and it is there introduced as a metaphor.
} 
In organization theory, the idea that an organization ends to be good at some particular thing (if anything) has long been referenced by the term "distinctive competence". This term was introduced by Selznick (1957) in his classic work Leadership in Administration. In Selznick'soriginal discussion, however, the idea of distinctive competence seems to be at least as close a relative of the organization's mission statement, or perhaps its "strategic intent" ( $\mathrm{H}$ amel and Prahalad, 1989) as of its capabilities. Selznick's concern is with theinfusion of means with shared ends: "thetransformation of an engineered, technical arrangement of building blocks into a social organism". H e suggests, as other management theorists have subsequently, that a highly effective organization emerges when a leader helps the organization to transcend a merely technical understanding of its own functioning. ${ }^{4} \mathrm{An}$ indicator of the distance from the capabilities concept is Selznick's reference to standardized building blocks; apparently it isthe value-laden "tranformation" and not the building blocks that account for the "distinctive" part. W hile Selznick (and others) may well be right to emphasize the importance of values, especially among the best organizations, capabilities theorists think the technical building blocks are often quite distinctive in their own right.

An influential article by Prahalad and $\mathrm{H}$ amel (1990) popularized the term "core competence". O nly a brief encounter with the article is required to notefour points: (i) that large corporations have multiplecore competencies (five or six at a maximum, they suggest, not twenty or thirty - but not one, either); (ii) that competencies are fundamental to the dynamics of the firm's competitive strength, lending strategic coherence to a string of new and improved products appearing over an extended period; (iii) that the competencies referred to are all areas of "hard technology" (if Procter $\&$ Gamble is properly thought to have core competence in marketing and distribution, and Carrefour and Wal-M art in logistics, the authors don't mention it); (iv) that while the relationship of competencies to large-scale structural features of the organization is a featured issue, the organizational aspects of the competencies themselves do not capture the author's attention. Some of the subsequent discussion of core competence seems to lose track of

${ }^{4}$ Peters and Waterman (1982) were emphatic on this point, see esp. Ch. 4. 
oneor more of these points. Thefact that the authors titled their article "T he Core Competence of the Corporation" (note singular) may have contributed to a partial eclipse of point (i). ${ }^{5}$

The last two points noted above are much at odds with the concept of organizational capabilities, which need not to relate to technology and certainly have significant internal organization. If, however, we simply ignore a couple of points, we can move closer to the capabilities concept by focussing on the first two. We then arrive at the idea that a successful large corporation derives competitivestrength from its excellencein a small number of capabilities clusters where it can sustain a leadership position over time. This comes very close to the concept of "dynamic capabilities" advances by Teece et al.. (1997:516): "we define dynamic capabilities as the firm's ability to integrate, build, and reconfigure internal and external competences to address rapidly changing environments". (Seealso Teeceet al., 2000a). In areas of "hard" technology, the dynamic capabilities of a firm depend heavily on its $R \& D$ resources; in other areas that label may not be applied but analogous investments aremade.

There is general agreement, however, that dynamic capabilities cannot be built simply by spending on $R \& D$ or making analogous investments. O n the contrary, coordination between $R \& D$ and other functions, and often with suppliers or alliance partners, is of the essence. Such coordination is needed, among other things, for effective identification and linking of technological options and market opportunities, and for identifying the strengths and weaknesses of existing resources rel ative to the requirements of a new product or process.

Thus the concepts of "core competence" and "dynamic capabilities" point in the same direction, being broadly concerned with the firm's ability to carry off the bal ancing act between continuity and changein its capabilities, and to do so in a competitively affective fashion. We shall not advocate terminological purism and remain content when no ambiguity arises, with analogical uses of "capabilities" and "competences".

\footnotetext{
5 The use of the singular in "core competence" encourages a conflation with "core business". In practice, "core business" seems to have primarily a historical connotation: your core business is the one you were in before you started (or resumed) diversifying. Recommendation that a corporation retreat to its core business do, however, seem to rest on the presumption that some resources offering potential competitive advantage do remain there, current poor performance notwithstanding. And there is a presumption that if you can't be good at your core business, you probably can't be good at anything else.
} 
H owever, after all these definitional tour de force, let us also propose for the future a narrower interpretation of the notion of competences which gives the latter a distinct meaning confined to a scale of observation intermediate between single routines and overall firm wide capabilities (as defined above), capturing "chunks" of organizational abilitiesidentified in terms of performed tasks and knowledge-bases upon which they draw. It is a usage well in tune with Patel and Pavitt (2000a), Patel (1999b) C antwell and Piscitello (1999a), which might usefully become a sort of standard.

So, one might talk of mechanical competences to capture, together, ensembles of skills of individual members of the organization and, at the same time, directly organization-embodied elements of knowledge, routines, etc. - all aimed at the design production improvement of, say, machine tools. $\mathrm{N}$ ote that, in this example, mechanical competences are not likely to fulfil the overall organizational capability of producing and effectively selling the machine tools themselves. 0 ther complementary competences will be required to that effect, concerning e.g. electronic technologies, marketing activities, etc.

If one accepts this interpretation of competences stricto sensu, some important consequences follow.

First, in line with Patel and Pavitt (2000a) one may begin to distinguish different but complementary types of competences concurring to determine the overall capabilities of an organization. Patel and Pavitt, in this respect, single out some distinctive functional features discriminating between background, core and niche competences of an organization, emphasizing at the same time their interdependencies: “. .. in sectors making and improving complex products and production systems... , firms require the broad range of technological competences that unable them to stimulate and integrate technological improvements by their suppliers of materials, components, subsystems and production equipment... ". Technological interdependence means that the notion of "focus" and "make or buy" applied in production and marketing activities, do not work in relation to technological competences" (Patel and Pavitt, 2000a:330).

Second, in this context, one is always referring to organizational competences bearing that the "competence of company $x$ in technology $y$ " is 
something different from "theensemble of theindividual skillsin technology $y$ of all the members of company $x " .6$

$H$ aving said that, it is useful to distinguish between what we shall call technol ogical and organizational competences [similar distinctions are made in D osi and Teece (1998), Coriat and Weinstein (2000) and Weinstein and Azoulay (1999b)].

The two types of competences are clearly overlapping in the empirical world. H owever, the distinction rests in that technological competences refer to shared pieces of scientific and technological knowledge and routines concerning essentially "the structure of nature" and "how to handleit", (turning a piece of metal into a particular structure, searching for a new chemical compound with certain functional characteristics or printing a circuit on a wafer of silicon are examples of the genre). Conversely, we shall call organizational competencesthose shared pieces of knowledge and routines concerning the governance of coordination and social interactions within the organization and with outside entities (customers, suppliers, etc.).

So, while it is straightforward that a technological competence requires some organizational arrangements in order to be put to work, it is al so truethat fundamentally similar bodies of technological knowledge might be nested in and exploited by diverse organizational arrangementsand coordination modes.

Indeed a significant part of this paper is devoted to: a) the exploration of the patterns in such diversities (even when holding strictly knowledge bases constant); b) the impact of organizational competence upon corporate performances; $c$ ) the role of organizational innovations; and d) the coevolutionary dynamics between organizational and technological competences.

So, for example, one of the topics tackled in Coriat (2000a) is the

\footnotetext{
6 So the foregoing notion of competence, stricto sensu, escapes the analogy with the usage of the term with reference to individuals with a connotation of breadth rather than specificity - something closer to judgement than to skill. Eliasson (1990), for example, discusses the role of the "top competent team" in the firm - the de facto top management team - which involves making strategic judgements that are not readily amenable to analysis. Such decisions are informed instead by the experienced-based tacit knowledge of individuals and by the dialectical interaction within the team. This sort of competence relates not to a specific subject matter or task, but to an entire realm of highly consequential decisions that are difficult to get right, where small percentage improvements over judgements of average quality can be very valuable. The character of decision- making in this realm, and in contexts in which both competence (or vision) and capabilities play an important role, has been explored by Fransman (1994a, 1994b).

Without at all denying the importance of such "strategic competences", as a first approximation we choose to leave them out of our narrow definition of competences, one reason being the lower organizational stickiness of the former. [With some pragmatism, especially when discussing Project-based organizations: cf. Dosi, Hobday and Marengo (2000b).
} 
organizational dimension of thechangefrom "Fordist" to "Toyotist" organizational arrangements; Florida and Kenney (2000a) and Lorenz and Lazaric (1999a) study the degrees of "hybridization" which Japanese modes of corporate organization undergo when transplanted into different institutional contexts; Coriat (2000c) discuss different pieces of evidence on the performances effects of diverse organizational arrangementsand innovationsthereof.

N oticethat is plausible that the "intermediate" level of observation where competences are detected - "coarser grained" than individual routines but functionally morespecific than overall capabilities- might bealso wherestatistical proxiesmight moreeasily befound. Proxies of innovative output such as patents have long been used but one is beginning to explore a richer variety of data concerning technology (e.g. innovation counts, linkages with scientific advances, etc.), skills profile of the employees and modes of organizational coordination and reward mechanisms (e.g. from just-in-time to TQC to the modes of governance of internal labour markets, etc.). ${ }^{7}$

\subsection{Technology and organization}

An ambitious effort is being made to advance and systematically link the investigations of "what is inside the technological blackbox" - paraphrasing Rosenberg (1982) - and of "what is inside the organizational blackbox". In fact the analysis of the former has largely proceeded under the headings of the "economics of innovation", studying the patterns of change in the knowledge basesunderlying innovativeactivities and the related dynamics of "technological paradigms" and "regimes". 8

Conversely, competence/capability studies have been undertaken to a good extent with astrategic management orientation - especially in $\mathrm{N}$ orth America. In any case, to repeat, technological knowledge is to a significant degree embodied within economic organizations which are also major players in its accumulation and improvement. M apping knowledge dynamics into organizational and industrial dynamicsis thereforea priority area of research.

\footnotetext{
7 On all these different angles of quantitative observation cf. Henderson and Cockburn (2000a), Pisano (2000a), Patel and Pavitt (2000a), Patel (1999b), Cantwell and Piscitello (1999a and b), Breschi and Malerba (1999b), Grandstrand (2000b), Lhuillery (2000b), Coriat (2000b), Giarratana and Torrisi (2000b).

${ }^{8}$ Cf. among others Dosi (1982) and (1988), Freeman (1982) and (1994), Pavitt (1999), Breschi, Malerba and Orsenigo (2000).
} 
For sake of illustration, consider for examplethe response of an industry to the appearance of a technology that provides a new way of performing functions of central importance to the industry's activities. Such episodes can be identified on a very large scale- such as the replacement of mechanical and electro-mechanical devices by electronic devices in a wide range of types of equipment, and - on a quite smaller scale- such as the successive generations of displacement of larger disk drives by smaller disk drives in computers. ${ }^{9}$

A common pattern in such episodes isthat the leading firms in an industry often seem to react slowly to the challenge, with the result that leadership passes to some of the pioneers of the new technology. Sometimes a previously leading firm even fails to survive, or has a very close call. This pattern is, of course, illustrative of Schumpeter's discussion of capitalism's 'perennial gale of creative destruction', which he saw as theessential contextual feature for 'every piece of business strategy' (1950: 83-4).

O neproblem isto understand why this happens. Another problem is to understand why it does't happen - the pattern described is not universal, and theintuitive expectation that a "bigger" technological change ought to makeit more likely is not always confirmed. Among a number of explanationsthat are complementary and hence difficult to untangle, considerations related to the nature of the adjustment of firm capabilities needed to cope with the challenge havereceived increasing attention. [For different perspectives, cf. Tushman and Anderson (1986), H enderson and Clark (1990), Pavitt (1999)].

Certainly, technology-specific modes of knowledge-accumulation are likely to shape and constrain the ways "particular firms do particular things". Relatedly, the combinatories amongst different competences are likely to be product-specific and possibly sector-specific.

\subsection{The "anatomy" of regimes of knowledge accumulation and their sectoral dimension.}

The taxonomical exploration of technology specific patterns of knowledge accumulation - of which an early largely cited prototype is Pavitt

\footnotetext{
9 Christensen and Rosenblom (1995); Christensen and Bower (1996); Christensen (1997).
} 
(1984) - is far from over. Indeed, onetries to advance our understanding both with respect to intersectoral differences and specific intertemporal patterns. Regarding the former, Marsili (1999b) studies the diversity of innovation patternsacrossindustrial sectors, attempting to identify a more refined taxonomy of technological regimes. Such regimesare based on industry-specific properties of search for technological improvements, sources of knowledge and nature of knowledge-bases. In linewith previous taxonomic exercises such as Pavitt (1984), Patel and Pavitt (1997), M alerba and O rsenigo (1996), Dosi et al. (1995), Breschi, M alerba and O rsenigo (2000), it builds on two basic conjectures, namely, that, first, notwithstanding theimportance of country-wide institutional factors, the properties of innovation processes are, to a significant extent, invariant across countries and specific to technologies or industrial sectors, and, second, somegeneral properties of innovation processes shared by populations of firms might be identified independently of a variety of idiosyncratic behaviours observableat firm-level. M oreover, $M$ arsili's work analysis another crucial dimension discriminating across regimes and having to do with technological entry barriers, stemming from diverse modes of access to novel opportunities by entrants as opposed to (possibly cumulatively learning) incumbents. [T heissue is studied also, from another angle, by Balconi (2000b): see al so below]. From complementary perspectives, thedifferences across diverse regimes arefurther refined in Breschi and $M$ alerba (1999b) with respect to the incumbents' vs. entrants' learning patterns, even within a broad singleindustry, i.e. electronics; and in C astellani and Zanfei (1999b) when analysing the role of industry-specific factors (electronic vs. chemicals) affecting M N C's growth and diversification strategies.

\subsubsection{Corporate specificities and technology-/industry-specific invariances in competence profiles}

At a very fine-grained level, one observes fascinating idiosyncrasies in organizational capabilities. ${ }^{10} \mathrm{~N}$ arduzzo, Rocco, and Warglien (2000a) are concerned with two sets of capabilities developed and implemented by a cellular

\footnotetext{
${ }^{10}$ See in particular Nelson and Winter (2000a) which put a microscope on the particularities of capabilities and learning.
} 
phone network company. O ne of these capabilities is for the installation of new stations. T he other is for maintenance and problem-solving. The authors use the study of these complex examples of capabilities as an opportunity to explore the usefulness, limits, and meaning of the treatment of capabilities as bundles of routines. They concludethat, in their caseat least, effectivecapabilities certainly do involvethemastery and use of certain routines, but al so theability to do particular and often idiosyncratic things that are appropriate to a particular context. The company studied has different operationsin different regions. The authorsalso explorethequestion of theextent to which capabilities, and practices, are company-wide, as contrasted with developing regional - or group-specific idiosyncratic elements. They conclude that thelatter are important.

Argote and D arr (2000a) are concerned with the apparently humble capabilities in making good pizza in an economical way. O ne of their central questionsistheextent to which learned capabilitiesarebuilt into particular people, and the mechanism and extent to which capabilities can be regarded as organizational, in the sense that individuals can come and be replaced without erosion of the capability. They also are concerned with the extent to which new learned capabilitiesaretransmitted and contained within an organization, in this case a set of franchiseoperations. A hallmark of the paper is detailed examination of theway knowledgeismadeorganizational, and spread throughout thefranchise.

Szulanski (2000a) is also concerned with the mechanism through which routines are made common across a group of related organizations, in this case the member banks of a bank group. The group of banks associated with Banc $O$ ne has been expanded through acquisition. Banks become members of the group because of the significant financial success that group members continue to have, and because of a strong belief that success is due in good part to certain bundles of routines that are used in all Banc $O$ ne operations. At the same time, the philosophy of Banc $O$ ne admits that individual units should have a certain freedom to accommodateto the particularities of their individual circumstances. The study describes in elaborate detail the processes through which a new acquisition of Banc $O$ ne system.

Flaherty (2000a) is concerned with learning and effective control in semiconductor manufacturing. In contrast with other technologiesconsidered by other papers in Dosi, Nelson and W inter (2000a), semiconductors 
manufacturing is extraordinarily complex. Thereare many different processes involved, and each process, and the interactions across the various processes, easily can get "out of control". There is a major problem in assuring quality of the output. A central problem, therefore, in semiconductor manufacture is to be able to spot quickly production aspects that seem to be getting "out of control", to diagnose and solve a problem can themselves be highly expensive in terms of lost production. Flaherty's study puts a microscope on these issues, and illustrates nicely the complexities that often are involved in organizational capabilities.

All the foregoing studies find an interesting complement concerned with dynamic capabilities. The firms under study are in industries where success in competition requires the capability to continuously introduce new products, and improveolder ones, and to develop new production processes to support and accommodate these product changes. Pisano (2000a) and $\mathrm{H}$ enderson and Cockburn (2000a) are about firms in the pharmaceuticals industry. Appleyard, $\mathrm{H}$ atch, and Mowery (2000a) is about firms in the semiconductor business. The capabilities studied relate to performance in doing $R \& D$, and the ability to learn and to solve problems more generally. Sometimes the orientation is toward the capability to learn how to learn.

Each of the studies looks at several different firms that have varied in their success in developing and implementing key dynamic capabilities. The studies are very much in the tradition of studies in business strategy, in that they have as a principal purpose the identification of factors that have made for successful strategies. But thesestudies al so add to our positiveunderstanding of the key capabilities of firms in industries where innovation is a central aspect of competition. Thus they contribute significantly to the further development of a positive theory of the firm that can fit into an evolutionary theory of industrial competition and development.

In each of the studies, the dynamic capabilities under examination are defined at a relatively broad level: the capability to develop manufacturing processes to produce new pharmaceuticals (Pisano, 1991), the $R \& D$ capabilities to design profitablenew pharmaceuticalsproducts (H enderson and Cockburn, 1994), the capability to implement new process techniquesin the semiconductor business (Appleyard, H atch, and M owery, 2000a). Each of the authors sees 
the broad capabilities in question as consisting of a collection of morenarrowly defined competences, and effective routines, brought together through mechanisms and organizational structures that influence how they work as a whole. Thus Henderson and Cockburn refer specifically to component competences, and architectural competences.

In each of the studies, the authors provide evidence of a combination of explicit and articulated, and tacit and sometimes subconscious, elements. Thus thefirms involved are able to articulate broadly the strategies that liebehind the capabilites they are employing, or at least present a theory or a myth about that.

On the other hand, in each of the studies it is apparent that the key capabilities involve bundles of routines which are strongly tacit in nature. And one comes away from reading these studies with the perception that, in none of the cases, did the firms involved completely understand what they were doing, at least at a relatively fine level of implementation (as such a healthy antidote against "cartesian" views of strategies!). Rather, firms appear to differ - well in tune with a basic premise of evolutionary theories - partly of choice, partly by chance and partly by history and context.

\subsubsection{Competences/capabilities in multi-technology, multiproduct, firms}

Together with in-depth studies focused on small sets of enterprises, we had pursued a parallel effort to identify more "bird eye" invariances in the nature of competence/capabilities - common to specific sectors, institutional arrangements, countries, technologies.

M odern corporations aretypically multi-competenceentities- in the sense that in order to do whatever they do they generally embody and combine diverse technological and organizational competences (cf. the definitionsabove) - , and they are often multi-product, multi-capability entities, too.

A few contributions attempt indeed to interpret the observed patterns in the former domain (with regards to both technological and organizational competences) and also try to map them into their actual activity especially with reference to the product diversification profiles. W ithin theseendeavours, Patel (1999b) studies the patterns of technological diversification (as such a reasonable 
proxy for the distribution of technological competences) in nearly 500 large technologically active firms based in Europe, Japan and the U SA.

The main findings, include the following:

- increasing technological diversification has become a more common phenomenon in the 1990's amongst firms in all product groups and nationalities;

- as a group, increasing diversifiers have expanded the volume of their technological activities, have much higher than average proportion of these activities in areas of high technological opportunity, and have increased their market share;

- on the other hand refocusing firms have a low proportion of their technological activities in fast-growing areas and have seen a decline of their share of technological activities. Their market share in all product groups has declined;

- at the firm level, there is a statistically significant positive relationship between increasing technological diversity and growth in the volume of sales and patenting.

- amongst the technologies that are becoming more important are both the(so-called) "high-tech" areas and themore "traditional" technologies.

Thefindingsindicatethat despitetheemphasis, especially in theconsultancy literature, on "refocusing" as a business strategy, large firms are becoming more diversified in terms of their technological competencies in the 1990's, and this process has gone hand in hand with growth in their volume of sales.

Further corroborating evidence comes from Piscitello (1999b) who (i) studies the patternsthrough which largefirms movein space of technologies and products over time, trying to highlight the differences in diversification patterns followed by European firms vs. their US and Japanese competitors: and (ii) attemptsto develop a methodological framework, based on a matrix representation, for the analysis of the many-to-many relationship between technological competencies and products. (Again, the evidence draws on a large panel of the biggest European, U S and Japanese firmsover the period 1977-1995).

Theanalysis highlights the processes through which large firms grow by 
diversifying their technological competences and, through that, also their product range. [For previousstudies mainly concerned with thetechnological side of the process, cf. Granstrand et al. (1997) and Pavitt (1998)].

Contrary to "common wisdom", not much evidence is there of "return to the core", "refocusing and specialization", etc. Rather, the picture is quite blurred. Certainly, there appears to be a quite widespread process at work of "creativeaccumulation" in technological competencescoupled with thedynamics of product diversification. Interestingly, amongst US firms variability in products diversification profiles is not accompanied by any pronounced trend while only E uropean and J apanese firms seem to generally reducethe number of their diversified activities. When crossing the geographical dimension with the sectoral one, it emerges that U S firms happen to be on average the most diversified - with a decreasing trend in pharmaceuticals, chemicalsand coal $\&$ petroleum and an increasing in all theother sectors. EU firmsshow an increasing business diversification in office equipment, aircraft, food, chemicals, rubber and plastic products and mechanical engineering.

$\mathrm{N}$ ote al so that business diversification reveals an increasing trend towards service sectors, particularly for European and, even more so, for U S firms.

Concerning the profiles of technological diversification, first, theevidence appears to corroborate the conjecture that the domains of technological diversification tend to bebroader than those of diversification in production [Pavitt (1998), Patel and Pavitt (2000a), Piscitello (1999b)]. As such, all this suggests that multipleinternal competences arenecessary even to simply sustain absorption and integration of technologiesand products generated outsidethefirm [C ohen and Levinthal (1989)]. So for examplecar-producing firms embody competences in plastics, even if they do not produce plastic products, just to beable to integrate the latter into an automobile.

Second, whilethereis evidence of the existence of pervasivetechnological competences- new and old (such asmechanical competences) - , even "specific" ones appear in multiplecapability profiles: hence al so one should not taketoo literally the distinction between "general purpose" and "specific" technologies [Piscitello (1999b)].

Third, one tends to observe a growing complementarity between competences traditionally associated with innovation and production in 
manufacturing, on the onehand, those related to services, on the other.

A highly complementary angle to study competences in multi-technology corporations is by explicitly focussing upon corporate innovation systems, as Granstrand (2000b) does. The analysis of a number of technology and management issues such as technology acquisition, technology diversification, internationalisation of $R \& D$, IP management and commercialization of new technologiesisundertaken on a comparative basisover a sample of corporations in Japan, Sweden and U SA.

O netends to observe relatively coherent (and diverse) corporate systems, whereby in-house R\& D is managed together with a mix of external technology acquisition strategies, with variouscontractual forms. Product casestudiesfurther show that external technology acquisition is associated with technology diversification into increasingly costly new technologies. M oreover, data at corporatelevel highlight a strong impact of technology diversification on $R \& D$ expenditures and corporate sales. A breakdown of corporations into strategic groups show that diversified "multech" corporations grow faster than other corporations, while "focused" corporations display a sort of "second best" strategy for growth. H owever, in order to realise growth through diversification it is of vital importance to gear technology management towards reaping economies of scale, scope and speed through coordination, conflict resolution and technology transfer. T hese all represent - as G randstrand (2000b) discusses new challenges to traditional in-house $R \& D$ management practices.

Indeed, when comparing managerial capabilities and other features of corporate innovation systems, one observes clear nation-specific features, especially Japanese ones. To a considerable extent the latter developed during a catch-up stage, but a challenging issue is the extent to which they are "stagespecific" and possibly dysfunctional to "frontier" technology management, or, conversely, whether they are conduciveto innovation also in the "forging ahead" stage. Theevidencefrom Grandstrand, subject to some qualifications, is inclined toward. Thelatter conjecture- for example with regards to the organizational arrangements fostering "integrative" capabilities between research and other organizational activities high up in the hierarchical ladder. The degreesto which other Japanese organizational practices have some sort of "universal" efficiency is also discussed by other studies concerning their international diffusion. 


\subsection{Individual skills and collective competences/capabilities}

Fundamental questions in the interpretation of the nature of organizational competences/capabilities concern - as al ready mentioned - first the loci wherethey reside, and, second, the extent to which they areadditive in the skills and knowledge of organizational members. Clearly, the questions have far reaching implicationsalso in terms of organizational learning.

In order to highlight some major underlying issues let us dramatize two alternative views. ${ }^{11}$

The first archetype, which shall call the modular view, holds that "organizational knowledge" is primarily a shorthand for the knowledge of the individuals belonging to theorganization. By the sametoken, in thisperspective, strong warnings come- as $\mathrm{H}$. Simon puts it - against "reifying the organization and talking about it as 'knowing' something or 'learning' something. [R ather], it is usually important to specify wherein theorganization particular knowledge isstored and who has learned it". (Simon, 1991). From a quite different angle, also visions of "H ayekian" ascendency come to a similar "individualistic" reduction of organizational knowledge: given diverse and socially distributed pieces of knowledgethecentral task of theeconomy isto assurethecoordination amongst multiple agents embodying diverse and complementary skills. It isin a similar vein, al beit from a different tradition, that, for example, G rant (1996) defines a firm as a knowledge integrating institution and emphasizes the organizational task of integrating specialized, people-specific competences.

$\mathrm{H}$ ere, one of course is far from denying the importance of individual skills as constituents of the broader organizational competences/capabilities.

H owever, largely in tune with an alternative, collective view, of organizational knowledge, let us suggest that competences have indeed a dimension which isnot easily reducibleto those of theindividual organizational number: "it is firms, not people that work in firms, that know how to make gasoline, automobiles and computers" (W inter, 1982); and, dynamically, "organizational learning isa social phenomena and cannot bereduced to individual learning processes of the members of the organization." (M arengo, 1996).

11 A more detailed discussions is in Weinstein and Azoulay (1999b). 
Let us suggest herethat organizational knowledgeisnot only incorporated into the heads of organizational members but also into a) a set of routines, other organizational practices and shared representations, and, b) a set of material artifacts which shape intra-organizational relations and individual behaviours (a germane discussion is in Cohen et al., 1996).

$\mathrm{H}$ ere, as well asin a few other domains of organizational theory, the hard challenge for the analyst isto identify approximate but relatively robust discrete types of organizational arrangements mapping them into distinctive competence/ capability profiles. It is an exercise that one has begun to undertake in Coriat and Dosi (1998a) - trying to spot the distinctive features of "Fordist" and "Toyotist" organizational arrangements.

\subsection{Organizational arrangements and competence profiles: some discrete types, from "traditional" industries to complex products and systems}

Coriat (2000a) studiesthespecificities of the "Toyotist" model of production organization precisely on the grounds of both diverse routines and of diverse combination thereof. M oreover, it is shown there, theroutines prevailing within the "Toyotist competence" a) call for a different distribution of individual skills (as compared to e.g. "Fordist" organizational patterns), and, b) whileprovidinga specific, relatively coherent, organizational of work reflect also equally specific governance structures, modes of control and compromises regarding conflicting interests.

Theanalysis of theToyota System [cf. al so Fujimoto (2000a)] abundantly illustrates the properties that routines as "programmes" for coordinated action draw upon a set of individual skillswhosepresenceisobviously necessary condition for their implementation. In turn, theelicitation of particular repertoires of action is constrained and shaped by "meta-routines" governing information distribution and information processing, allocations of tasksand decisional power. In that, to paraphraseWarglien (in Cohen et al., 1996), routinesand therelated competences have an "architectural dimension" going all the way from the physical layout of manufacturing artifact to theallocation of work individually or by teams, vertical or horizontal coordination, just-in-time programmed from downstream or upstream, etc. 
Car production - studied by Coriat (2000a) and Fujimoto (2000a) - as well as many other manufacturing activities display distinctive, firm-specific, slowly changing organizational architectures- with a well identifiable distribution of routines and competences.

But what about other activities such as those associated with the design and production of Complex Productsand Systems (CoPS) whereby organizational arrangementstend to bemuch more "plastic" and project-specific?

D osi, H obday and M arengo (2000b) and Coriat (2000a) study these activities, trying to identify the underlying "combinatorics" of competences. In order to do that the former work analyses the distribution of problem-solving abilities and of governance mechanisms associated with diverse institutional arrangements within and between firms. Thesetopicsarestudied from adifferent, complementary, anglealso in Coriat (2000c) who suggeststhenotion of relational competence - as a particular instance of organizational competences - enabling thecoordination and building of problem-solving complementaritiesacross diverse organizational entities (e.g. different firms, public agencies, etc.). M oreover, Coriat suggestsatypology of governancestructures, nested on different distributions of a) competences, b) property rights, and c) authority relations.

A few studies also highlight the double nature of routines [C oriat and Dosi (1998a)] - as both devices for problem-solving and mechanisms for monitoring and command. So, for example, both Fujimoto (2000a) and Coriat (2000a) study the "control" sideof theToyotasystem - including "visual control", self-monitoring and other control devices- and their evolution over time.

The "double nature" of organizational practices is al so one of the main topics of Coriat (2000a) who also argues that diverse institutional architectures, in the case of C omplex Product and Systems (C oPS), do not only entail diverse form of authority relations (cf. above) but also different levels of distributions of relational rents(i.e. rent accruing to agentsholding crucial relational competences in the networks of C OPS designers and producers).

A quite different but equally interesting domain of investigation, in Balconi (2000b) concernsthe competence and underlying distribution of skills in a rather wide ensemble of sectors - including "supplier dominated", "scale intensive", "science based" ones [in Pavitt (1984) terminology]. Traditionally, they had been largely unaffected by Taylorist/Fordist electromechanical 
automation but haverecently been deeply transformed by electronic automation technologies and measurement instruments.

The nature of the required individual skills, has profoundly changed. People no longer "do" things, but control that things are done correctly by automatic equipment. In controlling, they must exert some judgement and their ability in assessing anomalous situations is based both on some formal education (computer literacy included) and on the experience acquired on the job. In that terms proposed in the paper, their tacit knowledgeis complementary to a codified knowledge base. Thediscretionality they enjoy ishowever limited, since the responsibility to solve demanding problems is shifted to distinct engineering personnel.

The flattening of the hierarchical ladder and the broadening of the tasks assigned to shop floor workers appear to be to a large extent a consequence of i) the elimination both of most manual repetitive tasks and of tacit-skillsrequiring ones; ii) theincreasing reliability of equipment; and requiresiii) higher education levels of the workforce.

The famous pins of Adam Smith's example are currently made by an automated manufacturing lineso that one single worker sufficesto control both the smooth running of the equipment and product quality, undertake some machineset-up and makesomepreventivemaintenance. Theensuing division of labour amounts to a division of functions amongst workers with very different types of skills. At one extreme in the knowledge ladder - above the controller, just described -, specialist white-collars are assigned the conception of products and of manufacturing cycles. At theother extreme, below the controller, unskilled labourers carry out ancillary services, such as moving objects and cleaning.

Compare the skills distribution in the new (electronically automated) competenceprofileswith theolder (non-automated or, partly electromechanically automated) ones. Skills of the production workers are much less specific than they used to be, as they are grounded on more general knowledge. For workers it is easier to bemultiskilled and for firms it is often more profitableto rely on a multiskilled workforce. Inter-sector mobility of workers has become less demanding as well, in terms of thetime and difficulty of acquisition of "local" new knowledge. ( $N$ otealso that the number of this type of production workers tends to shrink). 
Conversely, at thehigher extreme of the knowledgeladder, organizational competences rely upon the complex, difficult-to-acquire, skills of expert problem-solvers and new knowledge creators.

\section{Patterns of learning and competence accumulation}

In acquiring and adapting their competences/capabilities over a period of time, organizations are doing something that can reasonably be called organizational learning. H ereagain there is a large literature embracing a wide range of specific intellectual ambitions, methodologies, and techniques. There are books that seek to speak directly to managers (a notable and influential examplebeing Senge, 1990). Facilitating certain types of organizational learning is a major objective of quality management, and thus the large literature of quality management provides another port of entry into the subject of organizational learning and hence to organizational capabilities. Classicsin the area include D eming (1982), and Juran (1989); for a recent assessment of the quality movement see Cole (1999). M ore recently, consultants and corporate executives have evinced great interest in "K nowledge M anagement", a rubric that seems to span a substantial number of distinguishable concerns- but some of these concerns clearly relate to the effort to improve capabilities through learning. ${ }^{12}$ In particular, the quest of improved performance through "benchmarking" and the identification and transfer of "best practices" is an activity that is widely and systematically pursued. Careful studies of the microprocesses of organizational learning havebeen conducted both in the field as in H utchins (1991), Adler (1993), and Von H ippel and Tyre(1995), and in thelaboratory [seeC ohen and Bacdayan (1994) and Egidi (1995), among others].

$\mathrm{H}$ owever, it is fair to say that organizational learning isstill another large but foggy sea.

Let us thus begin with somenotions on organizational learning and then move to some empirical evidenceon the processesthrough which firms acquire, build, modify and losetheir competences/capabilities.

\footnotetext{
${ }^{12}$ On this valuable reference is the special issue on 'Knowledge and the Firm' (R.E. Cole, ed.) of the California Management Review (v. 40, Spring 1998).
} 


\subsection{Organizational learning}

The two alternative archetypes of organizational knowledge which we called themodular and collectiveviews, find a mirror imagein therepresentation of organizational learning.

So, well in tune with the former, Simon (1991) emphasizes that strictly speaking "organizational learning" is only a metaphor since "all learning takes place insidehuman heads": thus, "an organization learnsin only two ways, (a) by the learning of its members, or (b) by introducing new members who have knowledges the organization did not previously have".

Conversely, whilenot denying at all theimportance of theforegoing learning modes, at least a few of the contributors share the "collective view" and attempt to disentangle- both in theory and from organizational evidence- the patterns of change of some sort of collective intelligence which organization embody: see, in particular, Levinthal (2000a), and M arengo et al. (2000b) on thetheory side; N arduzzo et al. (2000a), Fujimoto (2000a), Coriat (2000a), D osi, H obday and $M$ arengo (2000b) for empirical investigations, Warglien (1999b) on both.

Of course, both caricatures (the "modular" and the "collective" one) should not have difficulties in acknowledging that diverse organizational structures:

- foster learning by individual members of the organization in certain directionsand hinder it in others;

- affect the rates at which individual learn;

- shape the efficacy by which individual skills are exploited and contribute to the overall performance of theorganization, below, on interdependences and complementaritiesas key organizational features);

- affect the rates at which individual skills and broader competences are diffused throughout the organization.

Given all that, the "collective view" also adds that - as there is an intrinsically organizational dimension of organizational knowledgeembodied in the routines, hierarchical structures, culture of an organization -, so, dynamically,

- organizational learning of whatever origin goes together with changes in routines and possibly organizational structures; and 
- "in order to become organizational, the learning that results from organizational inquiry [and, we would like to add, also that absorbed from the environment] must beembedded in theimages of organization held in its members' mind and/or in the epistemological artifacts (the map, memories and programs) embedded in the organizational environment" (Argyris and Schön, 1996).

O rganizational learning is obviously linked with the change of individual skills - sometimes indeed with the loss of some of them -, but also with changes of collective representations, rules, and even of hierarchical set-ups [cf. N arduzzo et al. (2000a)].

In essence, organizational knowledge and organizational learning ought to be partly considered - in the "collective view" - as an emergent property, shaped by the interaction amongst multiple learning/adjustment processes occurring within the organization itself - ranging from the levels of the individual, to teams, departments, plants, etc.

Some important implications are also worth emphasizing:

I. the organizational nature of learning is also reflected by its being linked with changes in organizational practices which might not display any evident correlation with what individuals "know";

II. all forms of long-lasting organizational learning imply some mechanisms of codification of knowledgeand interaction procedures.

D espite a fundamental incompleteness of codification mechanisms themselves [for discussions on such a vexed debate cf. D osi, $M$ arengo and Fagiolo (1996), Pavitt (1987) and Industrial and Corporate Change, 2, Special Issue, (2000)], codification - also in the form of archives, documents, training practices, etc. - imperfectly deal swith the persistenceorganizational knowledge well beyond the mobility of organizational members.

Relatedly, the very codification of individual skills is a fundamental aspect of the establishment of an organizational memory.

III. O rganizational learning isnever a purely cognitive process: rather it finds a crucial ingredient in processes of social adaptation, learning and modification of organizational rules, development of shared interaction patterns, etc. 
In many respects, the point mirrors dynamically the relation between technological and organizational competences we made earlier. Changes in the collective "knowledge of nature" and the procedures to master it - being it related to the design and production of a new machine tool, a new drug, a new type of airplane, etc. - usually go together with changes in skills distributions, information flows, action patterns and sometimeseven "cultures" within theorganization. But the converse does not necessarily hold: onemay indeed observe even significant changes in the social division of labour, in action patterns, etc. without any dramatic change in the technical competences the organization holds. In fact, this lack of one-to-one correspondencebetween technological and organizational innovation is al so a necessary premise for the comparison of the performances of diverse organizational set-ups, when holding strictly technological knowledge roughly constant. In turn, this bears far-reaching implications in terms of comparative assessment of e.g. "the Japanese firm" vs. "the American firm", etc.

IV. Organizational learning is ridden with path-dependencies whereby incumbent competences shape and constrain the patterns of future exploitation.

O ne might not be prepared to subscribe Weick and Westley (1996) extreme view that "organizing and learning are essentially antithetical processes... to learn is to disorganize and increase variety". Still it should be relatively easy to acknowledgethe widespread occurrence of competencetraps, and lock-ins into history-reinforced specialization, "way of doing things", hierarchical arrangements, action pattern [cf. Levitt and M arch (1996), C ohen and Sprull (1996) Levinthal (2000a), Cantwell (2000), Marengo et al. (2000b)].

Incidentally, note also that assessment of the degrees of pathdependencies of organization learning bears again, important consequences for the comparative diagnostics of the diffusion of particular organizational formse.g. between Europe, theUSA and Japan. W ithout any path dependency, when observing a given diffusion pattern one may safely talk of "laps" and "leads" across regions and countries. However, the picture is much more blurred when path-dependencies matter, sincesomeorganizational innovations might yield superior performances in some context and given a particular history might not do so along other institutional and organizational paths. 


\subsection{Patterns of organizational learning and competence accumulation}

In the broadest definition, some form of organizational innovation (whether successful or not is a different matter) occurs whenever an organization changes its protocols for the coordination of the information and knowledge distributed across its individual members; for the monitoring and governance of its conflict of interest acrossorganizational members; and for the distribution of authority assignments. All this, to repeat, might or might not go together with changes in technological competences and organizational knowledge. $\mathrm{H}$ aving said that, a crucial but still largely unexplored question is how organizational innovationsoccur.

M orespecifically, onemay distinguish two "ideal types" of learning processes, namely, first, internal learning processes vs., second, acquisition of external competences and organizational models. N eedless to say, the real world displays varying combinations between thetwo modes. It appliesto technological learning (Cohen and Levinthal, 1989), and, equally so, to organizational innovation. $\mathrm{H}$ owever, it is useful to distinguish some specificities of each archetype.

Let us begin with internal learning and notice that, asfar as organizational competences are concerned, one hardly find any equivalent to $R \& D$ search concerning technological innovation. Thereisno functionally specialized locus invested with "organizational search". Rather, experimentation and adjustments are diffused throughout theorganization. But with that comedelicate problems of interpretation of experience, opaqueness in therelations between actions and outcomes, strictly "credit assignments" of successes and failures of theorganization [Argyrisand Schön (1996), Sproull (1981) and Levinthal (2000a)].

Path-dependencelooms largethroughout.

The problems associated with the acquisition of external practices and competences are those more generally stemming from forms of indirect experience. First, learning tends to concern primarily codified forms of knowledge. Second, issues of interpretation of "external models" and local adaptation remain fundamental, and with that al so the question whereas one can maintain that thereareidentifiable, relatively invariant, organizational models that are undergo interorganizational diffusion. 
M oreover, both "internal" and "external" forms of organizational learning entail subtle links with organizational structures. So, for example, as $M$ arengo (1992) emphasizesthereisan intrinsic tension between knowledgedecentralization - assuch a fundamental source of variety and experimentation -, and centralization which guarantees coherencein the exploitation of these diverse forms of learning. So, as M arengo (1992) putsit, "higher degrees of decentral ized learning arenot necessarily conducive to higher degrees of organizational learning": they are so, only in so far as the former "can be 'pulled together' and made coherent with the overall organizational learning process" (p. 19).

\subsection{Accumulation of technological competences}

Consider all the foregoing discussion as a sort of tentative roadmap in thelarge and foggy ocean of organization learning. G iven that, let us flag some contributions of research on several of these topics, beginning with learning processes which primarily concern theaccumulation of technol ogical competences and then moveto someevidence on the even foggier domain of organizational innovation.

\subsubsection{Patterns of interaction between firm-specific competences and location-specific attributes}

The interaction between firm-specific and distributed (but locationspecific) knowledge is studied from complementary angles by $C$ astellani and Zanfei (1999b) and Cantwell and Piscitello (1999a). The basic idea of the former is that multinational firms acquaintance with local contexts is a key asset increasing their ability to understand user need and to tap into local sources of application-specific knowledge.

These context-specific competencesinteract with generic firm-wide ones in determining the strategies of knowledge accumulation, investment and networking with local firms.

Theauthors on theground of a novel data set on international operations in which theworld'slargest electronics and chemical corporationswereinvolved in 1993-97, examine how multinational experience affects inter-firm linkage 
creation. Remarkable similarities and differences emerge across industries in this respect. First, specific multinational experience, measured by the extent and nature of a firm's presence in a given country, appears to positively impact upon commitment intensive international operations, such as mergers and acquisitions, in both electronics and chemical industries. This result is consistent with a "knowledge-based view" of the firm (combined with a "dynamic transaction cost" approach). Second, generic multinational experience, measured by the extent and nature of a firm's global operations, positively affects the creation of more "exploratory", non-equity linkages, in the electronicsindustry and not in the chemical industry, highlighting also theimportance of paradigmspecific knowledgein shaping internationalization strategies.

Cantwell and Piscitello (1999a) study - again for a large sample of world top firms - study the relationship between competence accumulation and internationalization strategies. Whilea good percentage of innovative activities in still undertaken at the home base (with the noticeable exception of some small European countries, such as the $N$ etherlands), one observes processes of internationalization of research aimed primarily at "tapping" locally generated opportunity, rather than exploiting existing ones.

Theinternational networks of M N C snow contribute positively to their technological diversity, by drawing on thelocational differentiation of innovation across the sites in which the M N C operates, and thereby reinforcing regional and national systems of innovation. In a complementary study $C$ antwell and Kosmopoulou (2000) show also how the internationalization of corporate technological development dependsupon the competitivestrength of nationallyowned firms in an industry (which encourages outward investment but may deter inward investment by foreign-owned firms in the same industry), and upon the importance of localized vertical linkages in innovation in a country (which may deter internationalization). Cantwell and Piscitello (1999b) investigateal so the geographical spread of M N C networksfor innovation within Europe, whether formed by European-owned or non-European-owned firms, paying particular attention to the relative attractiveness of locations for the technological development of foreign-owned firms, at a regional (sub-national) level within Europe. Amongst the results onefinds that, first, diversification in new locations is increasingly becoming a means by which firms extend their 
technological baseand capabilities, sinceinternationally dispersed development of technology might be a source of competitive advantage.

Second, and relatedly, the experience acquired in a specialized activity in onelocation is likely to createintra-organizational technological spillovers that can be passed on to the other parts of the multinational company.

Third, as far as the locations themselves are concerned, these patterns, other things being equal, are likely to increase asymmetries between "central", "intermediate" and "peripheral" regions, due to location-specific dynamic increasing returns. And a somewhat similar effect is likely to apply to firms themselves. So, for example, as Cantwell and Piscitello (1999b) argue, European firms originating from the major centers for their industries (e.g. the leading German chemical companies) are able to create cross-border European networks to diversify their corporate technology base, and while continuing to develop the principal technologies for their industry mainly at home, they can source related technologies in the appropriately specialized regions. As a result of such strategies of corporate European integration by the leading European M N CS, intermediate and lower order regions are able to deepen their established patterns of technological specialization, since the new research facilities of capable foreign-owned M N C S not only access the region's existing local skills and expertise, but locally build upon them and enhance them. $\mathrm{H}$ owever, since higher order regions attract a greater diversity of foreign-owned M N Cs, theimpact of M NC technological development within these regions is to widen their pattern of technological specialization, and to reinforce the general tendency for technological activity to geographically agglomerate in these areas.

A further implication, which bringsinto focus the effects of cross-border MNC development on smaller and more localized (non-multinational) European firms, isthat the kinds of technology spillovers which occur between firms within regions are likely to differ between lower order and higher order regions. In intermediateregions spillovers are typically intra-industry or at least involve a common set of broad technological fields, and hence reinforce the established pattern of specialization (such as within motor vehicle and related engineering in the West M idlands or Piemonte). Conversely, in higher order regions spillovers occur much more in fields of technology that are common 
to many industries, such as in general mechanical processes, information and communication technologies, or new materials, and theexistence of these kinds of localized network externalities increases the attractiveness of such regions for foreign-owned corporatetechnological development in general. The availability of localized technology spillovers within regions in turn increases the potential for foreign-owned affiliates to take on an independently technologically creative role within their international corporate groups, to which they are connected (among other things) by means of cross-border knowledge flows.

Yet another angle of investigation concerning the patterns of accumulation of technological competenceshas referenceto the role of collaborative agreements and collaboration-related policies. Theanalysisby G iarratana and Torrisi (2000b) utilizes a large database of European el ectronicsfirms. Thestudy does confirm the importance of collaborative ventures of various kind as a mechanism of technological learning. Interestingly, however, the evidence shows that effect is greater when collaborations involvenon-EU (mostly American) partners, while EU -sponsored collaboration do not appear to exert any significant influence upon innovative capabilities. The sample of firms does include the largest European firms only: hence may reasonably argue that EU policies have had mainly an impact upon diffusion of competences to the weaker and smaller partners of the collaboration. In any case, such an evidence ought to send significant warnings about the efficacy of European technology policies concerning the advancement of theinternational technological frontier.

\subsubsection{Discontinuities in knowledge-bases and corporate capabilities: the case of drugs and biotech}

General conjectures put forward in different fashions in D osi (1982) and Freeman (1982), and refined by several students of technology and organizations thereafter, are a) that the nature and patterns accumulation of organizational capabilitiesareintimately related with theunderlying technological paradigms, and b) that discontinuities in the latter might entail also significant changes in the required corporate competences and performance profiles.

Theseconjecturesareamongst thetopics explored by 0 rsenigo, Pammolli and Riccaboni (1999b) with referenceto biotechnology and thedrug industry. 
Biotechnology is a major new technological paradigm which has been deeply transforming the nature of therelevant competenciesand of thelearning processes in various industries, particularly in pharmaceuticals. The pharmaceutical industry used to be - and to a large extent still is - one of the sectors where Europe enjoyed relative and in some cases absolutetechnological and competitiveadvantages. H owever, over the past two decadesthese advantages have been partly eroded. US companies haveclearly taken thelead in innovation and sales. W ithin Europe, British firms have shown a remarkable performance, whilst the position of the German industry - which has been an absolute world leader for al most a century - has been deteriorating. Whilst thereisa considerable debateabout the reasonsand the extent of this decline, a wideconsensus appears to exist on the consideration that this (partial) decline is linked to the joint working of two main factors: a series of big technological shocks and a series of large institutional shocks (ranging from theintroduction of tighter regulations in the process of approval of drugs, to policies of cost containment of health expenditures, etc.). 0 rsenigo et al. explorehow these shocks (and especially the former ones) have impacted on different firms and national industries.

It has been argued [see, for exampleH enderson (1994), G ambardella(1995), $H$ enderson, O rsenigo and Pisano (1999), Pammolli (1997)] that theemergence of a new knowledgebase in the pharmaceutical industry, based on biology rather than on chemistry, has led to profound transformations in the procedures underlying drug discovery and in theorganization of theinnovative process within firms and among firms and other institutions (like University laboratories). Thedifferent response of both individual corporations and national industries to these changes is certainly a major part of the explanation of the aggregate trends of competitiveness in the sector. Two issues are particularly challenging.

First, the new knowledge base has a distinctive scientific nature and therefore it is, in principle, abstract, to a good extent codified, and - without the establishment of intellectual property rights- largely accessible to everyone. This makes the case of pharmaceuticals somewhat different from cases of organizational transformations driven by changes in more tacit competences such a with engineering knowledge. M oreover, there might be somewhat of a puzzlehere. Given these properties, how is it that firms and national industries reacted so differently to the "molecular biology revolution"? 
Second, another distinctive feature of the recent evolution of the pharmaceutical industry has been the emergence of a dense network of collaborative relations between varioustypes of firms (new specialized entrants, large established corporations, universities, etc.). W hat does explain this "organizational innovation" and what arethe variables driving the dynamics of the network over time?

O necan find in the literaturewidely different interpretations of thenature, motivations, structure and functions of these networks, ranging from more sociologically oriented approaches to economic explanations based on (various mixes of ) alternative theoretical backgrounds, e.g. transaction costs, contract theories, gametheory and competence-based accounts of firms' organization. In turn, these interpretations generate widely different predictions about the evolution of collaborativerelationshipsover time[Barley, Freeman and $\mathrm{H}$ ybels, (1992); Arora and G ambardella (1994); G ambardella (1995); Powell, D oput and Smith-D oerr (1996); O rsenigo et al. (1999b)].

For example, with reference to the case of biotechnology, collaborative relations have been often considered as a transient phenomenon, bound to decrease in scale and scope as the technology matures and as higher degrees of vertical integration are established in theindustry (Pisano, 1991).

In a rather different perspective, 0 rsenigo et al. (1999b) emphasize the role played by scientific knowledgein pharmaceutical research and theemergence and evolution of networks. In this vein, collaborations represent a new form of organization of innovative activities, which are emerging in response to the increasingly "formal" abstract nature of the knowledge bases on which innovations draw [Arora and G ambardella (1994), Gambardella, (1995)].

According to this approach, theinnovative process can be represented as a sequence going downstream from scienceto marketing, whereby division of labor can occur at every stage of the process.

Collaborationsarelikely to emerge, with a large (and possibly expanding) number of entities interacting with each other, generating an intricatenetwork within which organizations might specialize in particular technological areas or stages of theinnovative process.

Relatedly, the complex and interdisciplinary nature of relevant knowledge bases in pharmaceutical $R \& D$ tends to make technological innovations the 
outcome of interactions and cooperation among different types of agents commanding differentiated competencies and complementary resources [O rsenigo (1989); Pisano (1991); O rsenigo et al. (1999b)]. The structure of the network and the position of agents within it is thus instrumental in determining agents' access to relevant sources of scientific and technological knowledgetogether with innovative performances [see also Shan et al. (1994); Walker et al. (1997)].

$O$ rsenigo et al. suggest that the formation and subsequent evolution of the network of $R \& D$ alliances can be interpreted primarily as an adaptive response to the emergence of a radically new knowledge base within the industry, that is molecular biology. T his paradigm discontinuity did not only simplify the search space by providing more general theories. It also led to an explosion of the search space, significantly deforming it. Firms - both large established companies and innovative entrants especially at the research end may often master only fragments of the knowledge relevant to generate new chemical entities aimed at novel therapeutical targets. T hegrowing innovative opportunities, the branching of knowledge into increasingly specific and uncertain directions and - especially in the 1990s - the appearance of "transversal" technologies, have led to the generation of a wide variety of search trajectories, which however come under two broad families of exploration and technological advance.

The first pattern has involved a trajectory of increasing specification of biological hypotheses. The second has been progressing towards the devel opment of "transversal" techniques to generate and screen compounds and molecules.

In both cases, established $R \& D$-intensivepharmaceutical firms have been able to absorb the new knowledge by interacting with new entrants. In fact, the expansion of the network has been driven mainly by the entry of new agents embodying new techniques. The network has taken a distinct hierarchical structure, with different firms operating at different levels of general ity, which has been perturbed but not broken by transversal techniques.

Given such a resilience of the "international oligopolistic core" and its ability to adjust to the new competence requirements, it appears also that European (in particular continental European) firms have lost some of their 
innovative edge, possibly due al so to less rich opportunities of tapping local scientific advances.

\subsection{Inside the blackbox of organizational learning}

So far we have discussed those contributions focusing primarily on the patterns of technological learning and competenceaccumulation, whilehowever largely neglecting the detailed nature of intra-organizational processes. Conversely, the latter are central to the investigation of N arduzzo, Rocco and Warglien (2000a), Argoteand D arr (2000a) Szulanski (2000a) and Warglien (1999b).

\subsubsection{The evolutionary dynamics of intra-organizational projects}

Warglien (1999b) explores the idea that the dynamic processes through which firms accumulate and diffuse competences are evolutionary process. of course, the idea links up with literature on adaptive complex systems, which has much emphasized that evolutionary processes not only shapethe dynamics (composition) of populations of agents, but may indeed shape the internal processes through which agents learn and adapt [H olland (1975), Axelrod and Cohen (1999)]. Similarly, cultural evolution theories have stressed that social systemsaccumulate an diffusetheresults of individual or group experimentation and learning through processes that may be modeled as proper evolutionary dynamics (C avalli-Sforza and Feldman, 1989). Finally, there is now a pretty large stream of research in organization theory suggesting that there may be evidence for intrafirm "D arwinian" cycles of mutation, selection and spread of fittest variants (for a short review seeWarglien, forthcoming).

O ne of the contributions of Warglien (1999b) is to explicitly model such internal processes and look for empirical support to evolutionary views of the dynamics of firm competences through the analysis of a longitudinal case study. In particular, the paper reconstructs theintra-organizational evolutionary dynamics of design competences in a large European microelectronics firm, over a time span of about 20 years (1973-1993).

In the case study analyzed in the work, design competences can be meaningfully related to the processes embedded in products' design. This 
provides a simplekey for the research design, helping to single out a population of units carrying such traits (the population of product design projects) and suggesting to analyze the long term dynamics of such population.

The study has two main empirical parts. The first one can be properly labeled as "ecological analysis", whilethe second oneismoredirectly concerned with evolutionary issues.

The first part is an analysis of selective dynamics in the population of projects. This part brings two essential results on density and age dependence. D ensity-dependenceisgenerally acknowledged as themost fundamental property of populations subject to selective dynamics. Warglien shows that densitydependence characterizes the growth of the population of projects, affecting both birth and death process.

Age-dependence is a more problematic feature: in the context of microelectronic devices design, it can be interpreted as resulting form the contrasting effects of obsolescence (positive age dependence) and inertia and cumulative inter-project learning (negative age-dependence). Thestudy shows that even in short life-cycle industries such as microelectronics thelatter factors do matter.

After establishing the existence of selective pressures the work deal s with the evolutionary dynamics of competences.

First, the paper shows that the rates of innovation havewaveform behavior over time, and affect the risk of early mortality of new projects. This suggests that there are "Schumpeterian" internal cycles of regulation of the exploration/ exploitation trade-off within the firm. Warglien proposes the application of a new metric of evolutionary activity (mutuated from research in the artificial life domain) to gain further insights in the regulation of such trade-offs. Such metric highlights the existence of processes of learning to diffuse new design competences. Finally, the paper shows that theanalysis of competitivedynamics between competences supports a Lotka-Volterra like modeling strategy.

Besides these research results, this study has some potentially relevant implications for the management of innovation. Broadly speaking, the results obtained point to the necessity of managing competences in a dynamic perspective which emphasizes the control of the parameters regulating evolutionary processes, rather than looking at single projects. I suggest that the 
ability to tune the evolutionary process is a genuine dynamic capability of the firm, affecting its long term success.

First of all, the study reveals a need to govern the selection process. $D$ ata reveal a strong impact of crowding effects over project expected mortal ity rates. The sources of project mortality are not only external to the firm, but also relate to bottlenecks in internal resources and the decision making process.

Second, managing patterns of evolution requires a careful tuning of the exploration/exploitation trade-off. The portfolio of projects should comprise at any time a balanced set of new traits, which present high risk but also higher development potential, and well-established traits that provide resources for supporting the cost and the risk of exploration and stability and reliability in the relationships with market niches. $\mathrm{H}$ owever, the key point is that organizations need to perform simultaneously more exploration of new solutions and more exploitation of the results of former explorations. Reconciling these needs implies governing the diffusion process of successful new variantsin order to turn quickly new discoveriesinto profitable businesses. As Warglien shows, generating novelty does not warrant that novelty will successfully diffuse within the population of projects. Furthermore, the capability to absorb novelty into the population seems to vary with time, and is subject to learning effects.

\subsubsection{Duplication, transfer and international adaptation of organizational practices}

The international transfer of particular organizational practices is important in its own right and also in its bearings for the institutional specificities of organizational forms: e.g. to what extent can J apanese practices be successfully exported - even within the same company - across national/ institutional boundaries? And, conversely, to what extent do they undergo some "hybridization" due to local context condition?

Florida and Kenney (2000a) study the case of J apanesecar-manufacturing transplants in the USA. Their basic argument is that these transplants have effectively transferred and to some degrees replicated key organizational forms and capabilities at both intra- and inter-organizational levels. 
Lorenz and Lazaric (2000b) address a similar question and study J apanese transplantsin the UK and France.

Theinvestigation has two unique figures: first, they aim at thestatistical universe of the transplants, and, second, add variance to their observations by comparing two institutionally rather different host countries. Thestudy concerns characteristics of theorganizational structures, work practicesand human resource management (including training, internal careers, wage policies).

This comparative approach allows to draw more robust conclusions regarding the impact of local context conditions on what is transferred. A quantitativeappreciation of thetransfer of the work practices to the transplants is presented in Tablel.

TABLE ।

Organizational Practices of Japanese Affiliates

\begin{tabular}{lcc}
\hline & $\begin{array}{c}\text { Percentage of European Affiliates } \\
\text { than } 33 \% \text { of their Employees in the Practice }\end{array}$ \\
\hline Practice: & UK & France \\
\hline Job Rotation & 35 & 41 \\
Quality Circles & 29 & 18 \\
Self-Managing Teams & 27 & 25 \\
Employee responsibility for quality control & 75 & 73 \\
Multi-disciplinary Project Teams & 20 & 14 \\
Just in time production & 45 & 27 \\
\hline Number of respondents: & 55 & 22 \\
\hline
\end{tabular}

(N.B. None of the above percentage differences are statistically significant in Chi-Squared tests.)

Source: Lorenz and Lazaric (1999b).

Theresultsshow that J apanesestyle business practicesare being transferred, but that local context conditions result in modifications relative to the parent firm. Thus Japanese affiliates never look exactly like their parents. "H ybrid organization" is an appropriate term to characterise their European affiliates. Thesignificant differences observed concern the composition of skills on teams and the role of the supervisor or team leaders. Interviewees familiar with conditions in the Japanese parent firms invariably describe teams as learning 
organizations, in which the supervisor's or team leader's principal roleis that of a trainer and a technical problem-solver. Japanese supervisors have a deep and thorough knowledge of the product, and this allows them, in co-operation with operators, to resolvemost quality related problems without theintervention of engineers. Supervisors often lack this sort of expertise in the UK and, to a lesser extent, in France.

These differences in the way knowledgeis developed and distributed in teams appear to betied to specific features of each nation's system of professional training and to the way "careers" are structured in each country. Consider, for example, Britain with its deep social cleavages between manual operators and employees with technical qualifications. Thereonefindsalso astrong anticipation that acquiring a formal technical qualification is the first step in a career progression leading away from the shop floor. Consequently, it proves difficult to retain technically trained employees in employment on the shopfloor. In France, this poses less of a difficulty. If anything, the problem in France concerns school leavers, with a technical degree such as the BTS, who are 'parachuted' into positions of supervisory responsibility without the necessary on-the-job training which forms the basis for good problem-solving skills.

At a more theoretical level, these observations point to the way that routine practices connected to problem-solving skills are embedded in social and institutional context that matters Thelink between "external institutions" (mainly theeducation system) and problem solving devices implemented at theshopfloor level is thus highlighted (providing also further support to the notion that routinesgo well beyond any purely cognitive dimension, but need to be defined with reference to social context where they areintroduced.

$\mathrm{N}$ ote here that according to the authors, while their results point to significant differences between the payment systems of the affiliates in Britain and France relative to their parents, these differences do not appear to be connected with the ability of the Japanese M N C s to transfer their methods. This is not to say that payment systems do not matter for competitive performance. In fact, if a very robust correlation is found between the use of contingent or variable pay, which links compensation to various measures of performance, and the use of Japanese style business practices. H owever, the exact form these takes is influenced by local context conditions. (For example, 
Law plays a big role in France, much bigger than in the U K). H owever, there seem to be different ways of putting in place a system linking compensation to performance that respects local norms and law.

Another point regards the methods used to transfer the organizational knowledge and the routines. The study exhibits quite extensive use of human carriers of knowledge, reaching down to the lowest levels of the hierarchy. It is quite common for Japanese multinationals to bring over to Japan groups of operators from France or the UK at the time of the introduction of a new model. Similarly, it is quite common to send teams of Japanese operators over to the overseas affiliates. This practice distinguishes] apanese M N C s from their US or European counterparts. It points to the crucial roleplayed in the process of "O n-the Job-Training" practices and of the transfer of know how through "direct" learning. D espitethis efforts, and becausethesame conditions of training cannot be completely "transferred", one may observethat... "operatorsarenot involved in problem-solving and continuous improvement activities to the same extent astheir counterpartsin Japan. L ocal team leadersand supervisors often lack the necessary training and experience to impart these skills to operators."

Finally, the study suggests that despite "the labour market institutions of thetwo countriesdiffer in important respects" - a fact that explains "somedifferences in emphasis", - ... "Japanese multinationals operating in Britain and France have experienced comparable degrees of successin transferring their work practices. This ability to combineJapanesestylew ork practices with different national human resourcessystemspointsto a surprising universal ity of Japaneseorganizational forms", other readers of the same data might well bemore cautiousin their conclusions. $\mathrm{H}$ owever the evidence does support the idea that Japanese practices have a powerful "invasion potential" vis-à-visinstitutional contexts different from those where they emerged.

\subsection{The role and limits of the "markets for organizational competences": the case of consultancy firms}

Wehavethoroughly argued abovethat both competences and capabilities a) bear partly tacit features, and b) have a collective dimension irreducible to the sum of individual skills. Given that, what is there to be transferred via 
straightforward market transactions? And more specifically, what arethecentral objects of the transaction involving consultancy firms? Somefacets of an answer to this question are discussed in G arcia (1999b).

In brief, our conjectureis that the objects of transaction are primarily the following:

(i) Archetypes of quite standardized organizational protocols.

This is the case of rather codified templates for ensembles of routines such as "team work", "just-in-time", etc.

Firms "buy" these "ways of doing things" as sorts of generic organizational technologies, which - rightly or wrongly - are deemed to be quite universal and "superior" organizational arrangements.

(ii) M ore specific procedures generally associated with proprietary devices and software.

This is the case of e.g. training and software packages for information processing and support to decision-making (from the management of client portfolios all the way to modes of access to e-commerce and EVA techniques for financial management).

(iii) "M eta competences" and diagnostic capabilities.

The "upside" of the difficulties in decomposing organizational competences/capabilities is that they contribute to the "uniqueness" of each organization and its differential economic performances. The "downside" of the same phenomenon is the endemic ambiguity in the relation between organizational traits and organizational actions, on the one hand, and performances, on theother. Consultancy firms, or at least some of them, tend to specialize precisely in the diagnostics of such links - based also on their ability to observe multiple instances of the same basic practices across firms, across industries and across institutional contexts, and of "benchmarking" particularly successful ones.

(iv) External legitimization of internal managerial choices.

In many respects it is the "political" counterpart of theforegoing point : a purported "diagnostic" ability is put to the service of corporate management, which by itself might havefaced too big a resistance in the implementation of strategies which it had in any case al ready chosen (typical examples are layoffs, downsizing, "lean and mean" oganizational reorientation, etc.) 
(v) Selling "visions", keywordsand fads.

H ow much fad-paddling there is amongst the "competences" of consultancy firms is an issue too difficult to discuss here: $\mathrm{G}$ arcia (1999b) rather cautious view tends to suggest that thereis some, inextricably intertwined with the other objects of transaction mentioned above.

Come as it may, consultancy firms - theevidence appears to suggest - are both a) a fundamental vehicle of diffusion of "generic" organizational practices, and b) a crucial actor in the codification of such practices themselves (in fact diffusion is made possiblelargely by codification). Conversely, on the acquirer side, what one is getting is not only the adaptation of an archetypal protocol, but with it also the "crystallization" of a set of social practices, implicit decision biases, forms of authority relations and mechanisms of learning.

Given that, a challenging and open question concerns the importance for the European economy of the fact that the overwhelming majority of international consultancy firms arelikely to carry with them a $\mathrm{N}$ orth-American birthmark in the "organizational archetypes" they supply.

\section{Some conclusions}

This work - together with the twin article published in the previous issue of this Review - has explored at somelength a view of the firm centered on the specific abilities it embodies to "solve problems" - of both technological and organizational natures - and, at the same time, to "govern people". Such a view, which holds closelinks with evolutionary theories of industrial dynamics, bearsfar-reaching implicationsin terms of a) the internal structure of firms themselves, b) their approximate horizontal and vertical boundaries, c) the ways firms accumulate and modify the knowledge they embody, d) the processes through which knowledge istransmitted (or not) across organizational entities, and e) the ways specific firm-level capabilities and practices are embedded into broader institutional contexts. C onsider theforegoing examplesas just scratching the surface of a much wider interpretativechallange. 


\section{References}

Appleyard, M . M .; H atch, N. W.; M owery. D. C.,"M anaging the D evelopment of Transfer of Process Technologies in the Semiconductor M anufacturing Industry", in Dosi et al. (eds.), 2000.

Argote, L.;. Darr,. E, "Repositories of Knowledge in Franchise O rganizations", in Dosi et al. (eds.), 2000.

Argyris, C.; Schön, D . A., O rganizational Learning II. Theory, M ethod, and Practice, Addison-Wesley Publishing Company, 1996.

Arora, A.; Gambardella, A., "T he Changing Technology of Technological Change: General and Abstract Knowledge and The Division of Innovative Labor", Research Policy 23, p. 523-532, 1994.

Axelrod, R.; Cohen, M.D., Harnessing complexity, N ew York: Free Press, 1999.

Balconi, M., "Codification of technological knowledge, firm boundaries, and 'cognitive' barriers to entry", DYN ACOM Working Paper, $2000 \mathrm{~b}$.

Barley, S. R., Freeman, J.; H ybels, R. C., "Strategic Alliances in Commercial Biotechnology", in N ohria, N ., Eccles, R. G. (eds.), N etworks and Organizations, Cambridge, M a: H arvard Business School Press, p. 311-347, 1992.

Bezza, B., "A critical review of the major analytical perspectives on competencies, organizational learning and innovation, and the relationship between technological and organizational change", DYN ACO M Working Paper, 1999b.

Breschi, S.; M alerba, F., "D iversification and Specialization in Innovative Activities: An Analysis of Patenting Activity of Electronic Firms", DYNACOM Working Paper, 1999b.

; O rsenigo, L., "Technological Regimes and Schumpeterian

Patterns of Innovation", Economic Journal, v. 110, n. 463, p. 388-410, 2000.

Cantwell, J.; "Technological lock-in of large firms, since the interwar period", European Review of Economic H istory, 4, p. 147-174, 2000.

; Piscitello, L., "Accumulating technological competence - its changing impact on corporate diversification and internationalization", DYN ACOM Working Paper.; a revised version is published in Industrial and Corporate Change (2000), v. 9, n. 1, p. 21-51, 1999a. 
"Corporate Diversification, Internationalization and location of Technological Activities by MNCS: Differences between EU and non-EU Firms in the European Regions", DYN ACO M Working Paper, 1999b.

; Kosmopoulou, E., "W hat determines the internationalization of corporate technology?", DYNACOM Working Paper; a revised version is forthcoming in Forsgren, M .; H åkansson, H ; $\mathrm{H}$ avila, V., 2001, (eds.), Critical Perspectives on Internationalization, U niversity of U ppsala, $2000 \mathrm{~b}$.

Castellani, D.; Zanfei, A., "M ultinational experience, absorptive capacity and knowledge exploitation. A comparative analysis of the electronics and chemical industries", DYNACOM Working Paper, 1999b.

Cavalli-Sforza, L.L.; Feldman, M.W., Cultural Transmission and Evolution: a quantitative approach, Princeton University Press, 1981.

Christensen, C. M ; Bower, J. L., "Customer power, strategic investment and the failure of leading firms", Strategic M anagement Journal 17, p. 197-218, 1996.

; Rosenblom, R., "Explaining the Attacker's Advantage: Technological Paradigms, O rganizational D ynamics, and the Value N etwork", Research Policy, 23, p. 233-257, 1995.

The Innovator's D ilemma: When N ew Technologies C ause Great Firms to Fail, Boston: H arvard Business School Press, 1997.

Cohen, M. D.; Bacdayan P., "O rganizational routines are stored as procedural memory", O rganization Science, 5, p. 554-68, 1994.

; Sprull, L. S. (eds.), Organizational Learning, Organization Science, Sage Publications, 1996.

; Burkhart, R.; D osi, G .; Egidi, M .; M arengo, L.; Warglien, M .; Winter, S., "Routines and other Recurring Action Patterns of O rganization: Contemporary Research Issues", Industrial and Corporate Change 5, p. 653$699,1996$.

Cohen, W. M.; Levinthal, D. A., "Innovation and Learning: the Two Faces of Rand D", The Economic Journal, 1989.

Cole, R. E., M anaging Q uality Fads. H ow American Business Learned to Play the Q uality Game, N ew York: O xford University Press, 1999. 
Coriat, B., "The 'Abominable O hno Production System'. Competences, Monitoring, and Routines in Japanese Production Systems", in Dosi et al. (eds.), 2000.

; "Compétences, Structures de Gouvernance et Rente Relationnelle. Le cas de la Conception des G rands Projets Complexes", D YN ACOM Working Paper, 2000a.

; "O rganizational innovation in European firms. A critical overview of the survey evidence", DYNACOM Working Paper, 2000b.

; "The state of organizational reform in the European firms. Evidence from a comparative overview of ten EU countries", DYN ACO M Working Paper, $2000 \mathrm{c}$.

; Dosi, G., "Learning How To Govern and Learning H ow To Solve Problems: on the $\mathrm{C} 0$-Evolution of $\mathrm{C}$ ompetences, $\mathrm{C}$ onflicts and $\mathrm{O}$ rganizational Routines", in C handler, Jr., A. D .; H agström, P.; Sölvell, Ö (eds.), T he D ynamic Firm, O xford University Press, 1998a.

; Weinstein, 0 ., "O rganization and Institution in the generation of innovations", under revision for Research Policy, 2000.

Deming, W. E., O ut of the Crisis, M ass.: M IT Center for Advanced Engineering Study, 1982.

D osi, G., "Technological Paradigms and Technological Trajectories. A Suggested Interpretation of the D eterminants and D irections of Technical Change", Research Policy, 11, p. 147-162, 1982.

, "Sources, Procedures and M icroeconomic Effects of Innovation", Journal of Economic Literature, v. XXVI, September, 1988.

; M arsili, 0 .; O rsenigo, L.; Salvatore, R., "L earning, M arket Selection and the Evolution of Industrial Structures", Small Business Economics, 1995.

; M arengo, L.; Fagiolo, G., "Learning in Evolutionary Environments", IIASA, Laxenburg, Austria, Working Paper, 1996, forthcoming in K. Dopfer (ed.) Principles of Evolutionary Economics, Cambridge: Cambridge University Press, 2000.

; Teece, D.J., "O rganizational competences and the Boundaries of the firms", in Arena, R.; Longhi, C. (eds.), M arkets and Organizations, Berlin/ Heidelberg, N ew York: Springer-Verlag, 1998. 
; $M$ arengo, L., "O $n$ the tangled discourse between transaction costs economics and competence-based views of the firm: Some comments", DYN ACOM Working Paper, 1999b.

; H obday, M.; M arengo, L., "Problem-Solving Behaviors, O rganizational Forms and the Complexity of Tasks", DYNACOM Working Paper, 2000b.

; N elson, R.; W inter, S., "Introduction: The Nature and D ynamics of O rganizational Capabilities", in Dosi et al. (eds.), 2000.

et al. (eds.), The Nature and Dynamics of Organizational Capabilities Oxford: Oxford University Press, 2000.

Egidi, M ., "Routines, hierarchies of problems, procedural behavior; some evidence from experiments", in Arrow, K. J. (ed.), The Rational Foundations of Economic Behavior, London: M ac Millan, 1995.

Eliasson, G., "The firm as a competent team", Journal of Economic Behavior and Organization, 13, p. 275-98, 1990.

Flaherty, M. T., "Limited Inquiry and Intelligent Adaptation in Semiconductor M anufacturing", in Dosi et al. (eds.), 2000.

Florida, R.; Kenney, M ., "Transfer and Replication of O rganizational C apabilities", in Dosi et al. (eds.), 2000.

Fransman, M., "At and T, BT and NTT: a comparison of vision, strategy and competence", Telecommunications Policy, 18, p. 137-53, 1994a.

"Information, knowledge, visions and theories of the firm", Industrial and Corporate Change, 3, p. 713-58, 1994b.

Freeman, C., The Economics of Industrial Innovation, London: Pinter, 2a ed., 1982. "T he Economics of Technical C hange", Cambridge Journal of E conomics, v. 18, p. 463-514, 1994.

Fujimoto T., "Evolution of M anufacturing Systems and Ex Post D ynamic Capabilities", in Dosi et al. (eds.), 2000.

Gambardella, A., Science and Innovation. The U.S. Pharmaceutical Industry D uring the 1980s, Cambridge, UK: University Press, 1995.

Giarratana, M .; Torrisi, S., "Competence accumulation and collaborative ventures: evidence from the largest European electronics firms and implications for the EU technological policies", DYNACOM Working Paper, $2000 \mathrm{~b}$. 
Grandstrand, 0 ., "C orporate Innovation Systems A C omparative Study of M ultiTechnology Corporations in Japan, Sweden and theU SA", D YN ACOM Working Paper, 2000b.

; Patel, P.; Pavitt, K., "M ulti-Technology Corporations: why they have 'distributed' rather than 'distinctive core' competencies", California M anagement Review, Summer, v. 39, n. 4, p. 8-25, 1997.

Grant, R.M., "Toward a knowledge-based theory of the firm", Strategic M anagement Journal 17 (W inter special issue): p. 109-122, 1996.

$\mathrm{H}$ enderson, R., "T he Evolution of Integrative Capabilities: Innovation in Cardiovascular D rug D iscovery", Industrial and Corporate Change, 3(3), p. 607-630, 1994.

; Cockburn, I., "M easuring Competence? Exploring Firm Effects in D rug D iscovery", in Dosi et al. (eds.), 2000.

"M easuring Competence? Exploring Firm Effects in Pharmaceutical Research", Strategic M anagement Journal, v. 15, p. 63-84, 1994.

; Clark, K., "Architectural innovation: the reconfiguration of existing product technologies and the failure of established firms", Administrative Science Q uarterly, 35, p. 9-30, 1990.

; Orsenigo, L.; Pisano G. P., "The Pharmaceutical Industry and the Revolution in Molecular Biology: Exploring the Interactions between Scientific, Institutional and Organizational Change", in Mowery, D. C.; N elson, R. R. (eds.), The Sources of Industrial Leadership, Cambridge, $M$ a: Cambridge University Press, 1999.

H olland, J.H., Adaptation in natural and artificial systems, Ann Arbor (M I): University of Michigan Press, 1975.

H utchins, E., "O rganizing work by adaptation", Organization Science, 2: 14-39, 1991. Ichniowski, C.; Levine, D .; O Isen, C.; Strauss, G . (eds.), Theamerican, C ambridge: Cambridge University Press, 2000.

Juran, J. M ., Juran on Leadership for Q uality. an Executive $\mathrm{H}$ andbook, N ew York: Free Press, 1989.

Levinthal, D., "O rganizational Capabilities in Complex Worlds", in Dosi et al. (eds.), 2000. 
Levitt, B.; M arch, J.G., "O rganizational Learning, in Cohen, M. D.;. Sproull, L. S, (eds.), Organizational Learning, O rganization Science, Sage Publications, 1996.

Lhuillery, S., "The organizational practices of innovation and the performances of firms: an empirical investigation", DYNACOM Working Paper, 2000b.

Lorenz, E., "O rganizational R outines In the Light of 'O Id' Evolutionary Economics: Bringing Politics Back into the Study of O rganizational Learning", DYNACOM Working Paper, 2000b.

; Lazaric, N ., "T he Transfer of C ompetences to European-Based Japanese Affiliates", DYNACOM Working Paper, 1999b.

Lundvall, B. Â.; Christensen, J., "Extending and D eepening the Analysis of Innovation Systems with Empirical Illustrations from the DISKO Project", DRUID Working Paper, n. 99-12, Department of Business Studies, Aalborg University, 1999.

M alerba, F.; O rsenig, L., "Technological Regimes and Firm Behaviour", in D osi, G.; M alerba, F. (eds.), O rganization and Strategy in the Evolution of the Entreprise, London: M acmillan Press, 1996.

M arengo L.; D osi, G.; Legrenzi, P.; Pasquali, C., "T he structure of problemsolving knowledge and the structure of organizations", DYNACOM Working Paper, 2000b.

"Coordination and O rganizational Learning in the Firm", Journal of Evolutionary Economics, v. 2, p. 313-326, 1992.

"Structure, Competence and Learning in an Adaptive M odel of the Firm", in Dosi, G.; M alerba, F. (eds.), Organization and Strategy in the Evolution of the Enterprise, London: M acmillan, p.124-154, 1996.

Marsili, O., "Techological Regimes: Theory and Evidence", DYN ACOM Working Paper, 1999b.

Narduzzo, A.; Rocco, R.; Warglien, M., "Talking about Routines in the Field", in Dosi et al. (eds.), 2000a.

Nelson, R.R.; Winter, S.G., An Evolutionary Theory of Economic Change, Cambridge M A: H arvard University Press, 1982.

O rsenigo, L., The Emergence of Biotechnology, N ew York: St. M artin Press, 1989. ; Pammolli, F.; Riccaboni M., "Competencies, Technological Change and N etwork Dynamics. The case of the bio-pharmaceutical industry", DYN ACO M Working Paper, 1999b. 
Pammolli, F., Innovazione, concorrenza e strategie di sviluppo nell'industria farmaceutica, Ed. Guerini Scientifica, 1997.

Patel, P., "M easurement and Analysis of Technological Competencies of Large Firms", DYNACOM Working Paper, 1999b.

; Pavitt, K., "The technological competencies of the world's largest firms: complex and path-dependent, but not much variety", Research Policy, v. 26, n. 2, M ay, p. 141-156, 1997.

"The W ide (and Increasing) Spread of Technological Competences in the World's Largest Firms: a Challenge to Conventional W isdom", in Chandler, Jr., A. D.; H agström, P.; Sölvell , Ö. (eds.), The D ynamic Firm, O xford U niversity Press, 1998a.

"Uneven (and divergent) technological accumulation among advanced countries. Evidence and a framework of explanation", in D osi, G ;. Teece, D. J; C hytry, J., Technology, O rganization and Competitiveness Perspectives on Industrial Corporate Change, Oxford U niversity Press, 1998b. "H ow Technological Competencies H elp D efine the Core of the Firm", in Dosi et al. (eds.), 2000a.

Pavitt, K., "Patterns of technical of Change: Towards a Taxonomy and a Theory", Research Policy, 13:6, 343-73, 1984.

, "The 0 bjectives of Technology Policy", Science and Public Policy, 14: 4, p.192-8, 1987.

"Technology, Products and O rganization in the Innovating Firm: What Adam Smith Tells Us and Joseph Schumpeter Doesn't", Working Paper, SPRU, 1998.

Technology, M anagement and Systems of Innovation, Cheltenham, Edward Elgar, 1999.

,Academic Research in Europe", Working Paper, SPRU, 2000a.

Peters, T. J; Waterman, R. H .. In search of Excellence: Lessons from America's BestRun Companies, N ew York: Warner Books, 1982.

Pisano, G. P., "The Governance of Innovation. Vertical Integration and collaborative arrangements in the Biotechnology Industry", Research Policy, 20, p. 237-249, 1991.

"In Search of Dynamic Capabilities", in Dosi et al. (eds.), 2000. 
Piscitello, L., "Largest firms' patterns of technological and business diversification. A comparison between European, US and Japanese firms", DYNACOM Working Paper, 1999b.

Powell, W. W.; D oput, K. W.; Smith-D oerr, L., "Interorganizational Collaboration and the Locus of Innovation: N etworks of Learning in Biotechnology", Administrative Science Quarterly, 41, p. 116-145, 1996.

Prahalad, C. K.; H amel, G ., "T he C ore Competence of the Corporation", H arvard Business Review, May-June, p. 79-91, 1990.

Rosenberg, N., Inside the Blackbox, C ambridge: Cambridge University Press, 1982.

Selznick, P., Leadership in Administration: a Sociological Interpretation, Evanston, III.: Row, Peterson and Co., 1957.

Shan, W.; Walker, G.; Kogut, B., "Interfirm cooperation and startup innovation in the biotechnology industry", Strategic M anagement Journal June., $p$ 387(8), 1994.

Simon, H.A., Bounded Rationality and 0 rganization Learning, O rganization Science, 2, p. 125-134, 1991.

Sproull, L. S., "Beliefs in O rganizations", in Nystrom, P.C;. Starbuck, W. H (eds.), $\mathrm{H}$ andbook of Organizational Design. Oxford, UK: O xford University Press, 1981.

Szulanski, G., "Appropriability and the Challenge of Scope", in D osi et al. (eds.), 2000a.

Tushman, M.; Anderson, P., "Technological discontinuities and organization environments", Administrative Science Quarterly, 31, p. 439-65, 1986.

Von Hippel, E.; Tyre, M. J., "How learning by doing is done. Problem identification in novel process equipment", Research Policy, 24, p. 1-12, 1995.

Weick, K. E.; Westley, F., "O rganizational Learning : Affirming an 0 xymoron", in Clegg, S. R.; H ardy, C.; N orth, W. R. (eds.), M anaging Organizations, London: Sage Publications, 1996.

Weinstein, 0 .; Azoulay, N., "Firms' capabilities and organizational learning. A critical survey of some literature", DYNACOM Working Paper, 1999b. 